\title{
Olga Kosińska
}

Uniwersytet Jagielloński

Instytut Kultury

\section{Muzeum w domu - działania $w$ trakcie pandemii}

Po ogłoszeniu w Polsce i na świecie kolejnych obostrzeń związanych z pandemią koronawirusa kultura stosunkowo szybko podjęła działania związane z działalnością wirtualną, dzięki której kontakt z nią był nadal możliwy mimo zamknięcia takich instytucji jak teatry czy biblioteki. Muzea na świecie także dość sprawnie przeniosły swoją aktywność do internetu — jedynej przestrzeni, w której z pewnością $24 \mathrm{~h}$ na dobę znajdowali się jacyś odbiorcy. Wymuszenie działań cyfrowych ujawniło i spowodowało kilka zjawisk.

Po pierwsze wydaje się, że wyścig o uwagę użytkowników wygrały te muzea i galerie, których zasoby w momencie ogłoszenia ograniczeń już przynajmniej w jakimś stopniu posiadały zdigitalizowane zbiory. W pierwszej kolejności zaoferowano to, co już wcześniej znajdowało się na stronach internetowych muzeów i galerii - obrazy, rzeźby oraz inne artefakty dostępne w formie cyfrowej. Zaraz jednak pojawiły się nowe inicjatywy — głównie możliwość wirtualnego zwiedzania całych muzeów lub poszczególnych wystaw. W Luwrze można było przechadzać się po galerii starożytnego Egiptu, pozostałościach fos, Galerii Apollina, a także mniejszych wystawach przygotowanych w tzw. małej galerii (Petite Gallerie) [www.louvre.fr, data odczytu: 11.05.2020]. Podobne działania miały miejsce chociażby w muzeach w Berlinie [www.smb.museum, data odczytu: 11.05.2020], również oferujących szeroką gamę zdigitalizowanych zbiorów wraz z opisami, czy madryckim muzeum Thyssen-Bornemisza, gdzie dzieła podzielono na ścieżki tematyczne [www. 
museothyssen.org, data odczytu: 11.05.2020]. Nie inaczej działo się w Muzeum Narodowym w Warszawie [www.cyfrowe.mnw.art, data odczytu:11.05.2020] czy Muzeum Narodowym w Krakowie [www.zbiory.mnk, data odczytu: 11.05.2020]. Hasztag \#museumfromhome umożliwił stworzenie przestrzeni, w której w jednym miejscu pojawiały się cyfrowe działania muzeów [www. sr.ithaka; data odczytu: 11.05.2020].

Po drugie dookoła zbiorów cyfrowych, oprócz wirtualnych ścieżek zwiedzania, powstały dodatkowe aktywności. Na profilu Muzeum Sztuk Pięknych w Wiedniu na YouTube dostępne są wywiady, rozmowy oraz analizy i prezentacje poszczególnych dzieł [www.youtube.com, data odczytu: 11.05.2020]. Muzeum Narodowe w Warszawie rozpoczęło z końcem kwietnia inicjatywę pomocy tegorocznym maturzystom przygotowującym się do egzaminu z historii sztuki. Można było także wziąć udział w wirtualnych warsztatach dla dzieci, spotkaniach z kuratorami czy konserwatorami [www.mnw.art, data odczytu: 11.05.2020]. Tego typu aktywność nie pojawiła się nagle wraz z koronawirusem — w jakimś stopniu prowadzona była już wcześniej, jednak okoliczności odosobnienia i zamknięcia w domach spowodowały jej wzmożenie.

Po trzecie, co w zasadzie być może najciekawsze, można było zaobserwować sporo działań mających na celu zaktywizowanie publiczności i tworzenie user-generated content, a więc treści tworzonych przez samych użytkowników. Ich powstawanie jest jednym ważnych elementów wskazujących na aktywne zaangażowanie odbiorców w działalność instytucji. Stosunkowo łatwo jest kliknąć w dzieło sztuki i przeczytać jego opis lub nawet załączyć wcześniej nagrane oprowadzanie po wystawie. Bardziej jednak wartościowym z perspektywy muzeum jest wywołanie osobistego zaangażowania w tworzenie treści przez jego odbiorców. Największą tego typu pandemiczną akcją jest wywołany przez muzeum J. Paula Getty'ego w Los Angeles Getty Images Challenge, zwane także home art challenge (wyzwanie domowej sztuki) lub isolation art challenge (wyzwanie sztuki w izolacji). Polega ono na odtworzeniu wybranego dzieła z pomocą trzech rzeczy, które każdy może znaleźć we własnym domu [www.boredpanda.com, data odczytu: 12.05.2020]. Można więc zobaczyć infantkę Małgorzatę Teresę w niebieskiej sukience wzorowanej na obrazie Diego Velázqueza, tyle że zamiast ogromnej spódnicy dziewczynka stoi na rozkładanym namiocie ozdobionym papierem toaletowym. Fragment Ogrodu ziemskich rozkoszy Hieronima Boscha odtworzony został z pomocą garnków i domowych kotów. Kolorowe, abs- 
trakcyjne czworokąty Pieta Mondriana zastąpiły równie barwne ubrania [www.mymodernmet.com, data odczytu: 12.05.2020]. Pamiętać także należy, że nie jest to pierwsza i jedyna taka akcja — już wcześniej wystartowało holenderskie konto na Instagramie Tussen Kunst en Quarantine (Między Sztuką a Kwarantanną), odtwarzające i zachęcające do odtwarzania dzieł w podobny sposób [www.instagram.com; data odczytu: 12.05.2020]. Tego typu działania cechuje kilka rzeczy. Przede wszystkim — jak większość aktywności wirtualnych - nie są one w żaden sposób ograniczone przez granice państw. Znane dzieła nie wymagają znajomości języka obcego, by móc je zidentyfikować i zrozumieć — dzięki temu z łatwością mogą one rozprzestrzeniać się w skali globalnej. Są działalnością oddolną, nad którą żadne muzeum czy galeria nie ma kontroli — jednak dobrze wykorzystane stanowić mogą trampolinę nie tylko dla poszerzenia grupy odbiorców, ale także zacieśnienia relacji z już aktywnymi użytkownikami. Pozwala zatem tworzyć wirtualną społeczność zgromadzoną wokół instytucji, złożoną w części zapewne z osób, które dotychczas nie pojawiły się w muzeum osobiście. Z pewnością tego typu zadania mają także element edukacyjnychoć brane są pod uwagę raczej dzieła znane niż niszowe, wciąż stanowić mogą one źródło wiedzy i informacji dla osób wcześniej się danym artystą czy stylem nie interesujących.

Równocześnie jednak nie można popadać w hurraoptymizm. Kultura, a wraz z nią muzea i galerie, stara się poradzić sobie z przedłużającymi się ograniczeniami na różne sposoby, niektóre dalece kreatywne. Nie oznacza to jednak, że po „powrocie do normalności” wiele się zmieni. Nierzadko łatwiej jest zaangażować ludzi w odtworzenie Krzyku Muncha z pomocą swetrów i rękawiczek niż skłonić ich do przyjścia na wystawę czy wzięcia udziału w warsztatach. Zaangażowanie wywoływane i wzmacniane z pomocą różnego typu wirtualnych aktywności może przełożyć się w przyszłości na realne działania odbiorców — trudno jednak jednoznacznie stwierdzić, że tak będzie. Na plus z pewnością można zapisać wymuszone przez okoliczności zainteresowanie niektórych, dotychczas nie aż tak aktywnych w internecie muzeów swoimi kanałami w mediach społecznościowych czy stroną internetową. Tego typ działania mogą zostać na podobnym poziomie także po ponownym otwarciu tych instytucji, co wydaje się działać na ich korzyść [www.nemo.org, data odczytu: 12.05.2020]. Przesunięcie bliżej w stronę odwiedzających nie nastąpiło rzecz jasna dopiero w związku z pandemią — jednakże kryzys nią wywołany zdaje się jeszcze wzmacniać 
tego typu tendencje. Zmęczenie ograniczeniami wywołanymi przez skutki koronawirusa odbija się jednak także na kulturze - wzrost zaangażowania w akcje takie jak Getty Images Challenge jest chwilowy i nie przekłada się tak łatwo na bezpośrednie skutki dla muzeów. Pozostaje on także poza ich kontrolą - co nie oznacza, że nie powinny one starać się go stymulować i z jego pomocą przyciągać do siebie odbiorców.

Co roku 18 maja obchodzony jest Międzynarodowy Dzień Muzeów-Dzień Muzealnika. Tegoroczny wyglądał zgoła inaczej niż zwykle. Choć w tym samym dniu weszły w życie nowe wytyczne dotyczące ograniczeń związanych z koronawirusem, które pozwalały na powolne otwarcie niektórych instytucji kultury, w tym muzeów, sami muzealnicy spędzili swoje święto w dużej mierze online. Zwyczajowo pełna kolejek i tłumów w niektórych ośrodkach Noc Muzeów odbyła się wirtualnie [www.krakow.pl, data odczytu: 19.5.2020], a życzenia przekazywane były także w dużej mierze z pomocą internetu. Zarówno instytucje, jak i indywidualni muzealnicy czy widzowie nie tylko dziękowali sobie wzajemnie za ogrom pracy, ale także życzyli jeszcze więcej wytrwałości i zaangażowania w odnajdywaniu się w świecie po-pandemicznym. Bez względu na to, kiedy ostatecznie zdjęte zostaną ograniczenia związane z koronawirusem, okres zamknięcia stanowił spore wyzwanie dla organizacji kultury, nie tylko z perspektywy finansowej czy administracyjnej, ale także społecznej - czy społecznościowej. Internet pozwala na utrzymanie kontaktów i relacji nie tylko pomiędzy pojedynczymi osobami, ale także całymi instytucjami i grupami. Nie mogą się one równać działaniom i interakcją offline - nie takie mają też zadanie. Wirtualne zbiory, spotkania, akcje czy konwersacje są ważne - i zwyczajnie odmienne od tych wydarzających się fizycznie. Obydwa te poziomy przenikają się dość gładko bez względu na to, czy wokół szaleje akurat pandemia czy nie - obecny kryzys stanowi więc szansę dla niejednej instytucji na przesunięcie akcentów i wypracowanie całościowego podejścia do kwestii cyfrowych. Pozostaje więc dołączyć się do życzeń i wypatrywać świata, jaki wykształci się do czasu kolejnego Dnia Muzealnika.

\section{Strony internetowe}

\section{Barnes Sara}

2020: Spanish Facebook Group Has People Transforming Themselves Into Artwork While in Quarantine. https://mymodernmet.com/quearteencasa-home-artchallenge/?fbclid=IwAR1c-zjxMaka584mcOqoWZkRFJ_NiJJmIIS6ZbfUEkb3 LGWeY4QtqkWMqEk. 
Cyfrowe zbiory Muzeum Narodowego w Warszawie

2020: http://cyfrowe.mnw.art.pl/dmuseion.

\section{Grinevičius Jonas, Nefas Li}

2020: Museums Ask People To Recreate Famous Paintings With Anything They Can Find At Home, Get 35 Hilarious Pics. https://www.boredpanda.com/art-recreation-at-home-museum-challenge/.

Kim są polscy użytkownicy TikToka?

2020: https://www.gethero.pl/raport-tiktok/.

Lectures / Talks \& Interviews

2020: https://www.youtube.com/playlist?list=PLDoWx4K015JbGiDQ-HmL2qf0OmqYHJFcE.

\section{Louvre - online tours}

2020: https://www.louvre.fr/en/visites-en-ligne

\section{Maturalne SOS}

2020: https://www.mnw.art.pl/edukacja/oferta-edukacyjna-online-na-czas-kwarantan ny/maturalne-sos/.

\section{Międzynarodowy Dzień Muzeów inny niż zazwyczaj}

2020: https://www.krakow.pl/aktualnosci/239957,33,komunikat,miedzynarodowy_dzien_ muzeow_inny_niz_zazwyczaj.html.

\section{Museum virtual tours}

2020: https://www.museothyssen.org/en/thyssenmultimedia/virtual-tours.

\section{Oferta edykacyjna on-line na czas kwarantanny}

2020: https://www.mnw.art.pl/edukacja/oferta-edukacyjna-online-na-czas-kwarantanny/.

Overview of the Staatliche Museen zu Berlin Offers Online

2020: https://www.smb.museum/en/whats-new/detail/ueberblick-der-online-angebote-derstaatlichen-museen-zu-berlin.html.

\section{Sweeney Lisa}

2020: To Survive This Pandemic, Some Museums are Pivoting to Virtual Engagement. https:// sr.ithaka.org/blog/to-survive-this-pandemic-some-museums-are-pivoting-tovirtual-engagement/.

\section{Survey on the impact of the COVID-19 situation on museums in Europe}

2020: https://www.ne-mo.org/fileadmin/Dateien/public/NEMO_documents/NEMO_Corona_ Survey_Results_6_4_20.pdf.

\section{Tussenkunst en quarantine}

2020: https://www.instagram.com/tussenkunstenquarantaine/?hl=en.

Zbiory cyfrowe Muzeum Narodowego w Krakowie

2020: https://zbiory.mnk.pl/pl/strona-glowna. 


\section{Olga Kosińska}

\section{Museum at home - activities taken during the pandemic}

The outbreak of the coronavirus pandemic significantly affected all aspects of human life, including the daily activities of cultural institutions. During the period of closure to the public, museums undertook various initiatives aimed at keeping the attention of the current audience, as well as attracting new visitors - only this time in a virtual form. These activities were largely based on previously digitized collections, which almost overnight (if they had not been made available before) appeared in the digital space. Various forms of virtual tours (whether alone or with guides) were proposed, as well as other activities around digital artifacts, such as interviews with curators, analyzes of works, and workshops for children. The initiatives of the audience themselves were also important - such as the home art challenge, consisting in recreating a selected work of art with the help of objects at hand. This type of involvement gave a good chance of transferring it in the post-pandemic world to the ground of relations in the physical space of the museum - however, it does not mean an automatic unification of visitors around an institution that will take care of itself. Regardless of external circumstances, extensive measures should be taken to combine offline and online activities in modern museums.

Keywords: activities of cultural institutions, virtual tours, COVID-19 pandemic, digitization of collections 